\title{
Beyond the Usual Suspects and Towards Politicisation: Immigration in Quebec's Party Manifestos, 1991-2018
}

\author{
Catherine Xhardez ${ }^{1,2}$ (D) Mireille Paquet $^{1}$ \\ Published online: 4 August 2020 \\ (C) Springer Nature B.V. 2020
}

\begin{abstract}
Immigration is increasingly politicised: issues surrounding immigration are more salient and party immigration positions are becoming more polarised. Literature on this topic has overwhelmingly focused on Europe and the USA, while identifying radical right parties and particular social dynamics as the main drivers of politicisation. In this paper, we consider a case that exhibits growing politicisation, yet does not fit existing measures and explanation of this phenomenon: Quebec, Canada. Considering party manifestos between 1991 and 2018, we ask: how have Quebec major political parties treated immigration policy issues over time? We argue that Quebec's immigration partisan space is organised by a liberal-restrictive immigration policy continuum and a jurisdictional axis. Mapping provincial political parties' positions, we document a stable clustering towards liberal policy positions but a clear cleavage on the jurisdictional axis. We show that the emergence in 2012 of a highly moderate centre right party - the Coalition Avenir Québec - broke with these established positions and drove a politicisation of the issue. These results demonstrate the importance of considering alternative drivers to explain the politicisation of immigration, as well as of paying attention to the politics of immigration in contexts where pro-immigration discourses dominate.
\end{abstract}

Keywords Immigration · Politicisation $\cdot$ Quebec $\cdot$ Party manifestos

Electronic supplementary material The online version of this article (https://doi.org/10.1007/s12134-02000764-3) contains supplementary material, which is available to authorized users.

Catherine Xhardez

catherine.xhardez@concordia.ca

1 Centre for the Study of Politics and Immigration (CSIP), Concordia University, Montreal, Canada

2 Department of Political Science, Concordia University, 1455 Boulevard de Maisonneuve O, Montreal, QC H3G 1M8, Canada 


\section{Introduction}

The politicisation of immigration refers to a rise in the importance of immigration in political life and is made visible, within party systems, by an increased and often systematic polarisation of parties on the subject of immigration (van der Brug et al. 2015). It is usually explained by the mobilisation of radical right parties (RRPs) or by the influence of social dynamics (including changing immigration levels) that generate opportunities for all political parties to take stances on immigration. This paper considers one case of such politicisation, the 2018 general election in the Canadian province of Quebec, in which these two central drivers were absent. The winning party - the mainstream centre right party Coalition Avenir Québec (CAQ) - committed to reduce immigration levels, to implement tests, and to claim more immigration powers for the province. Midway into the campaign, the sitting Quebec premier Philippe Couillard (Parti libéral du Québec) recognised that immigration was indeed 'the ballot box question' (Chouinard 2018; Fletcher 2018). The emphasis put on immigration during the 2018 campaign as well as the newly elected government's actions $^{1}$ indicates an increasing politicisation of immigration in the province. Yet, commonly accepted explanations to account for this phenomenon seldom apply to the case of Quebec.

Up to this point, the literature has been mostly concerned with exploring the politicisation of immigration in Europe, where it has been both very visible and quickly evolving (e.g. Dennison and Geddes 2018; Grande et al. 2019; Green-Pedersen and Otjes 2017). The research on the politicisation of immigration has yet to be applied to Quebec and adapted to its peculiarities. Indeed, in Quebec and in Canada generally, discourses on immigration tend to be different from Europe, given the underlying image of Canada as a welcoming land of immigration (Bloemraad 2012). In addition, Quebec does not have a successful RRP, the literature's dominant explanation for the politicisation of immigration (van Spanje 2010; Grande et al. 2019). Although Quebec is a subnational entity in a federation, the province has substantial authority over immigration since 1991 and consequently selects most of its immigrants (Paquet 2019; Xhardez 2020). Moreover, party politics in the province has been historically structured around the question of Quebec's relationship with Canada, rather than the traditional left-right cleavage (Montigny and Gélineau 2019).

These differences demonstrate the need to adapt the tools and concepts developed to study the politicisation of immigration to cases that do not fit the dynamics occurring in Europe and in the USA. Non-traditional cases - which include not only subnational entities but also communities with very low immigration levels - can also experience immigration politicisation and must be studied. To do so, this article argues for the importance of studying the politicisation of immigration by considering case-specific configurations of the immigration partisan space, as opposed to cross-case systematic measures. This means mapping the particular organisation of political cleavages over immigration and tracing how political parties have positioned themselves over time. Such an approach implies to not equating politicisation with the rise of antiimmigration party stances and instead ask what party position corresponds to a move

\footnotetext{
${ }^{1}$ One of the first bills passed by the CAQ has completely reformed Quebec's immigration system (Bill 9).
} 
away from the dominant discourses, leading to party polarisation (i.e. opposing positions).

Applying this approach to the case of Quebec, this article asks: how have major political parties in Quebec discussed immigration policy issues over time? In answering this question, this article takes into account that the drivers of politicisation and the political outputs stemming from politicisation are strongly contingent on context (Carvalho and Ruedin 2018). As little is known about the immigration partisan space in which the parties of Quebec operate and their polarisation when it comes to immigration, this article studies provincial party manifestos since 1991, using a sentence-by-sentence codebook (Ruedin and Morales 2017; Ruedin 2019) and a multidimensional grid to map party positions on two axes (see Appendix C). First is an immigration policy axis, determined by a liberal-restrictive continuum, which considers immigration volume, origins, and types. Second, as Quebec's partisan space in which immigration is debated is not structured following a right-left cleavage, we add an original axis regarding jurisdiction, which underlines party position regarding the level of government that should manage immigration: Canada, Quebec, or both.

Using this multidimensional grid, this article demonstrates a relative stability of major political parties between 1991 and 2018. Parties in Quebec have clustered in around the liberal side of the immigration partisan space but have positioned themselves differently in relation to the jurisdictional axis. The findings also show that the CAQ has been the agent of politicisation of immigration by, as of 2012, introducing novel commitments to reduce immigration levels and to renegotiate the institutional immigration arrangements. These proposals broke with the established positions and discourses within Quebec's immigration partisan space but are far from radical when compared with party discourses in Europe or in the USA. The CAQ's contribution to politicisation is only visible in relation to the specific configuration of Quebec's immigration partisan space.

After reviewing the literature on immigration politicisation, this article presents a conceptualisation of Quebec's immigration partisan space and describes the methodology used to analyse party manifestos. Next, the positions on immigration of the four mainstream parties active in Quebec between 1991 and 2018 are traced, using the 'restrictive/liberal' and 'Canada/Quebec' axes. A concluding section discusses the implications of this study for scholars of immigration and politics.

\section{The Politicisation of Immigration}

The politicisation of immigration refers to the rising salience of immigration in political life (van der Brug et al. 2015) and is useful to account for the fact that 'immigration has moved from being almost a non-issue to being an issue that receives some party attention' (Green-Pedersen and Otjes 2017, 4). While the tendency has been to equate politicisation to a restrictive approach, it is not necessarily the case. Politicisation signals that immigration is now a topic around which elections can be fought and won. This has been explored heavily by scholars of political parties; however, this trend deserves attention from immigration scholars as politicisation has important political and programmatic consequences. Indeed, research shows that increased politicisation of immigration can reshape the political space in which the issue is debated. Moreover, increased attention and party competition around the topic calls into question models of immigration politics based on interest group dominance or elite consensus. 
There is no one-size-fits-all explanation for the drivers and the consequences of the politicisation of immigration. In political science, leaving aside social movement studies, two families of explanations coexist to account for it. These mirror general explanations of agenda-setting and explanations concerned with electoral strategies: demand-side and supply-side explanations of politicisation. Our approach underlines the importance of applying these explanations while keeping in mind the endogenous forces at play within each case, which include the institutional context in which parties and government evolve, the history of partisan dynamics, and the dominant political cleavages structuring political debates.

The first considers how changes in objective conditions and contextual parameters generate societal pressures that translate into political parties taking positions on immigration and more attention being paid to immigration issues. Macro accounts have considered changing values, growing economic and cultural insecurities, and the establishment of new political cleavages as creating a terrain for populist and exclusionary politics (Alonso and da Fonseca 2012; Inglehart and Norris 2017). At another level, the impact of rising immigration levels, changing public opinion, and other variables such as economic downturn or unemployment rates have been tested, with conflicting results (Hainmueller and Hopkins 2014; Morales et al. 2015; Grande et al. 2019; Dennison and Geddes 2018). In case studies, focusing events have proven to sometimes have a triggering effect on the politicisation of immigration (van der Brug et al. 2015). Terrorist attacks, murders, and other events, 'sudden [...], relatively uncommon [and] reasonably defined as harmful,' (Birkland 1998, 54) have been documented as causes of the growing salience of immigration (Lawlor 2015). These effects, however, are not always durable and unfold in relation to the particulars of each political context. Demand-side explanations demonstrate that politicisation is not automatic or the direct consequence of 'objective pressures': it is the result of decisions by political actors and is strongly affected by political institutions and party competition, as well as media framing (Abou-Chadi 2016b; Morales et al. 2015).

Supply-side explanations propose that the strategies of parties and elites are necessary to unite the demands stemming from societal grievances and changing contexts, while also exploring the actors' capacity to politicise immigration in the absence of demand factors. Radical right parties (RRPs) have been identified time and time again as the drivers of increased politicisation (Schain 2002; van Spanje 2010; Grande et al. 2019). Generally promoting anti-immigration ideologies and policies, they tend to include immigration in their manifestos and are thus sometimes able to capture voters concerned about the issue. RRPs' strategies of immigration entrepreneurship (Hobolt and de Vries 2015) have been shown to have transformative effects on party systems and on the content of the political agenda as a whole (Abou-Chadi 2016a). Through the processes of 'contagion' (van Spanje 2010), RRPs can force mainstream parties to take a position on immigration to avoid losing part of their traditional vote share (Abou-Chadi 2016a) or to maintain the capacity to build governing coalitions (Green-Pedersen and Otjes 2017; Carvalho and Ruedin 2018). A growing body of literature is also exploring the role of mainstream parties in politicising immigration-this process depends on their ideology, access to resources, and traditional base (Bale 2008; Meyer and Rosenberger 2015). These studies demonstrate convincingly that party strategy matters tremendously for the politicisation of immigration, notwithstanding contextual factors, and that once set 
in motion, the process of politicisation has long-standing effects on electoral and party politics (Grande et al. 2019).

These insights must be adapted by taking into account the specifics of the situation in Quebec. ${ }^{1}$ Indeed, demand-side explanations have little traction to explain this case. When compared with Western Europe, public opinion remains comparatively proimmigration. Strong anti-immigration views are not the norm in Quebec; Quebeckers favour immigration but are more uneasy with its potential linguistic consequences and with the growing diversification of Quebec society (Turgeon and Bilodeau 2014; Bilodeau et al. 2018). Levels of immigration to the province are stable and objectively low (see Appendix A, Table A2). More importantly, most of the immigrants coming into Quebec are directly selected by the provincial government and a majority of them enter the province as skilled economic migrants (Paquet 2017, 2020). When it comes to supply, current explanations are also of limited help. Quebec has yet to see an RRP enter the electoral arena and mainstream provincial parties continue to express a strong disapproval for anti-immigration movements such as 'La Meute' (the Wolf Pack). Because of the first-past-the-post electoral system, the convention of party discipline, and of the norm of responsible government associated with Quebec's Westminster parliamentary system, Quebec has never experienced a coalition government. These institutional features greatly limit the capacity of an RRP to enter the mainstream political arena and make electoral gains in the province. This, in turn, limits their potential ability to influence the province's party system through contagion or to affect government policies as members of a governing coalition. Indeed, analysing immigration and integration proposals of the two leading Quebec parties between 1976 and 2016, Rivard (2017) has found that brokerage dynamics created incentives for parties to adopt centrist and converging positions on these issues.

\section{Concepts and Methodology}

To account for the specificities of the Quebec case, this article maps the province's immigration political space and traces the evolution of parties' positions in that space over time. This was done in three steps: (1) conceptualisation of the case-specific configuration of the immigration partisan space, (2) primary data collection of immigration statements in mainstream party manifestos, and (3) use of a sentence-bysentence codebook to code immigration statements for each party over time.

The first step was to establish a conceptualisation of the immigration partisan space in Quebec, using existing insights about the politics of immigration and party politics in the province. This is in line with the insights of Ruedin and Morales $(2017,2)$ who warn against applying general and decontextualized models of party competition when considering party position in immigration. ${ }^{2}$ Quebec's unique situation as a Frenchspeaking province within the Canadian federation and Quebec's particular immigration

\footnotetext{
$\overline{2}$ This is especially important since scholars studying immigration and politics in Quebec have given less attention to immigration issues compared with language and identity matters. The literature has productively studied issues of diversity, identity, and immigrant integration, with many works studying i.e. reasonable accommodations (e.g. Laxer et al. 2014), secularism (e.g. Tessier and Montigny 2016), and Quebec citizenship (e.g. Gagnon and Iacovino 2007). However, with the exception of case studies paying attention to a specific subset of parties in the province (Stateless Nationalist and Regionalist Parties) (Erk 2014; Hepburn 2011), a detailed account of political parties' positions regarding immigration is missing.
} 
powers are the two features structuring this space. Historically, Quebec sovereignty and the province's relationship with Canada have structured, even polarised, the electorate rather than an ideological left-right cleavage (Montigny 2016; Montigny and Gélineau 2019). In practice, this has meant that the central distinction between mainstream political parties has been whether they believed that Quebec should remain within the Canadian federation or whether they fought for Quebec independence. This continuum has had consequences for a myriad of issues on which Quebec parties have had to take stances on, including decentralisation, language politics (Bélanger 2014), and social policy (e.g. Béland and Lecours 2005) within the federal regime.

Since the 1960s, the Parti Libéral du Québec (PLQ) has been the central proponent of Quebec staying within the Canadian federation while the Parti Québécois (PQ) has been the main party supporting Quebec independence. Since the 1990s, these two parties had dominated the provincial political scene until new parties emerged in the early 2000s. This time frame also includes the second referendum on Quebec independence, in 1995, which was led by the PQ and yielded an extremely close victory for the 'remain in Canada' option (50.58\%). This second referendum and the result shook Quebec's party system, calling into question the future of the independence movement and supporting the emergence of new parties.

Between 1994 and 2011, l'Action Démocratique du Québec (ADQ) acted as third party, promoting more autonomy for the province as well as limits to government spending and interventions (Boily 2008; Tanguay 2013). Then, the Coalition Avenir Québec — created by ex-PQ MP and minister François Legault — absorbed the ADQ in 2012 and became a new political force in the province. Known for its fiscally conservative approach and for its focus on economic growth, the CAQ presents itself as a nationalist party but rejects Quebec sovereignty (Boily 2018). In addition, Québec Solidaire (QS) was established as a party in 2006, through a merger of left-leaning parties and social movements, with the aim of supporting left-leaning policies and Quebec sovereignty.

Beyond the 'national question', the politics of immigration in Quebec is also structured by the actual policy jurisdiction of the province. While being a subnational government, Quebec has an unprecedented capacity to act in immigration based on the 1991 CanadaQuébec Agreement relating to Immigration and Temporary Admission of Aliens (hereafter: the 1991 Agreement). Still in force today, the 1991 Agreement transferred most jurisdiction over the selection of immigrants to Quebec as well as all integration services, with a financial compensation from the federal government (Houle 2014; Garon 2015; Paquet 2019). The federal government remains responsible for border control, levels and categories of immigration, refugee determination and selection, and family reunification and has a final say on all admissions. More importantly, Ottawa maintains full control over citizenship and naturalisation. Consequently, as opposed to other subnational governments and Canadian provinces, Quebec has an effective capacity to make immigration policy and this is bound to be reflected in the province's politics of immigration (Daniel 2006; Barker 2015). However, this capacity always operates in relation to the federal government and thus has the potential to overlap with the political divisions associated with views on Quebec's place in Canadian federalism.

Given these considerations, Quebec's immigration partisan space is conceptualised as a two-dimensional space. First, an immigration policy axis (Bale 2008) which helps 
account for what parties promise to do ('restrict' or 'liberalise' immigration). Second, a jurisdiction axis to account for how parties propose to achieve their immigration goals within Canada's federal system and which level of government they promote (federal, provincial, or status quo). This new conceptualisation allows for a fine-grained analysis of the content of party manifestos, while other methods pay more attention to quantifying the salience of different issues in documents (for example, the Comparative Manifestos Project) or have not always fully tackled the emerging issue of immigration (for an evaluation of existing approaches, see Ruedin and Morales 2017; Dancygier and Margalit 2019).

The immigration policy axis reflects, in a crude way, the general distinctions between parties' anti-immigration and pro-immigration stances. However, as discussed by Adam and Deschouwer $(2016,2)$, this assessment must be nuanced: '[...] dichotomous continuums are useful starting points, but too blunt to fully capture the range of party positions on immigration. A party can be negative towards refugees, but open to economic immigration, or the other way around.' For this reason, building on Czaika and De Haas (2013), the analysis disaggregates immigration policy proposals into three thematic issues to assess their liberal or restrictive character.

First, 'volume' which includes concerns with immigration levels, quotas, and more broadly, with 'objectives to increase or reduce migration flows or to retain them at current levels' (Czaika and De Haas 2013, 489-90).

Second, 'origins' which refers to particular regions, countries, linguistic, or ethnic origins of prospective international immigrants.

Third, 'types' which corresponds to positions to support or decrease different categories of immigrants (skilled migrants, entrepreneurs, refugees, international students, etc.).

The jurisdiction axis replaces the right-left axis usually mobilised in research on parties and immigration. It illustrates the 'centre-periphery' cleavage that opposes the proponents of more powers for the 'centre' (the federal government) to those supporting the 'periphery' (the provincial government). This axis reflects the centrality 'the national question' in Quebec, as divergent views on sovereignty and federalism have traditionally been at the heart of Quebec's party politics (Bélanger et al. 2018, 64). This second dimension demonstrates what impact, if any, traditional party dynamics in Quebec politics (i.e. the sovereignty-federalism positioning) have on immigration commitments in party manifestos.

In the second research step, we collected party manifestos from mainstream political parties between 1991 and 2018: the Parti Québécois (PQ), the Parti Libéral du Québec (PLQ), the Action Démocratique du Québec (ADQ), the Coalition Avenir Québec (CAQ), and Québec Solidaire (QS). This time frame was selected to reflect the structuring impact of the 1991 Agreement on contemporary immigration politics in the province. Party manifestos are widely used in comparative research on immigration polarisation: they signal parties' positions regarding immigration in a context of electoral competition (Ruedin and Morales $2017,2)$. They also present the considerable advantage of allowing for a retrospective analysis of partisan proposals (Ruedin 2019, 208). For this article, French language manifestos have been collected from the POLTEXT platform, which 
provides a database of all Canadian electoral manifestos. ${ }^{3}$ The corpus includes 29 documents, which are listed in Appendix B.

Statements on immigration were manually extracted from each manifesto. To do so, every manifesto was fully read, and human coders manually selected sentences of the party manifesto that referred to immigration policy as such. Building on the delineation made between immigration policies, which encompass the regulation of immigration and control of aliens, and integration or immigrant policies, which cover the actions aimed at the immigrants once they settle in the destination society (Hammar 1985, 5; Gest and Boucher 2018, 13), we only selected sentences directly related to immigration, i.e. parties' commitments aimed at attracting, facilitating, or limiting the settling of foreign people. While this distinction is theoretical (Gest and Boucher 2018; Filindra and Goodman 2019), it remains a useful tool to study political parties' responses to the question 'who should enter and stay?'

Third, the sentences identified in step one have been manually coded using our conceptualisation of the Quebec immigration partisan space. To do so, a sentence-bysentence codebook (see Appendix C) was used to position each engagement on immigration on the immigration policy ('restrictive-liberal') and jurisdiction ('Canada-Quebec') axes. This method has been proven to be robust and efficient in identifying immigration party positions, while allowing for nuances (Ruedin and Morales 2017; Ruedin 2019). Using this approach makes it possible to map how political parties position themselves within the political space and to trace the evolution of their position over time. Coding was conducted manually using computer-aided qualitative data analysis software (Atlas.ti) which offers opportunities to consistently analyse large quantities of texts, to code various quotations, and to develop networks of quotations (Kelle et al. 1995). For reliability purposes, each manifesto was coded multiple times and cross-validated across the two coders. To illustrate our analysis, the quotations are presented in the text as references in brackets (e.g.: [party, year, dimension, number]) (for the original quotations, see Appendix D). ${ }^{4}$

\section{Quebec Political Parties and Immigration over Time}

This section traces how Quebec mainstream parties have positioned themselves in the immigration partisan space between 1991 and 2018. This period covers eight general elections. Table A12 (see the appendix) lists the vote share of each party and the number of members elected to the Quebec's National Assembly for each election, with the party forming government marked with an asterisk. During that period, the PLQ formed the government four times, the PQ three times, and the CAQ once. In 2007, the PLQ formed a short-lived minority government and in 2012, the PQ also governed as a minority.

A central finding of our analysis is that, in Quebec, immigration has generally not been discussed at length in party manifestos. From 1991 up until the 2018 election, the analysis demonstrates that party positions remained relatively stable over time. During that period, mainstream Quebec parties occupied their particular space and the distance

\footnotetext{
3 The texts used come from the collection of political texts made available at www.poltext.org by the Center for Public Policy Analysis (CAPP) from Laval University, with the financial support of the Fonds de recherche du Québec - Société et culture (FRQSC).

${ }^{4}$ For the complete data (quotations extracted) and results of the coding, see [https://catherinexhardez. com/publications/].
} 
between parties' positions remained generally comparable. Up until 2012, Quebec parties' immigration positions also remained quite similar when it comes to the three dimensions of the immigration policy axis; cross-party variations were more visible along the jurisdiction axis. As the results show, this equilibrium was affected by the arrival of the CAQ in 2012, since the party took stances on immigration that challenged the status quo on both axes of the partisan space. Over time, these positions forced other parties to modify their positions, as was seen in the 2018 election.

\section{Parti Québécois}

Volume and immigration levels as such were rarely mentioned in the PQ's manifestos. Only in 2003 did the party document include a statement highlighting the need to increase immigration intakes 'to address the demographic challenge' in the near future (PQ, 2003, volume 48:3). Although the number of immigrants to be welcomed by the province was a major subject of discussion during the 2018 electoral campaign, in that year, the party took no official stance in its manifesto and called for the province to 'depoliticise' the question of immigration levels by removing this function from the hands of the government to instead make it the responsibility of the Auditor General of Quebec (PQ, 2018, volume, 1:34). The PQ's strategy was then to avoid discussing immigration levels directly by framing it as a technocratic issue.

Successive manifestos showed a clear insistence on the French language. Already in 1994, the PQ proposed the prioritisation of the arrival of immigrants fluent in French 'to aim for a majority of total flows' (PQ, 1994, origins, 59:16,59:45]). In 2018, the PQ vowed to make knowledge of French a pre-arrival condition for selection as an immigrant to Quebec (PQ, 2018, origins, 1:37). Doing so, the PQ demonstrated a significant stance towards the 'Francophone area' (PQ, 2008, origins, 22:21) and specific regions of origin for potential immigrants (e.g. France, francophone Belgium, Africa, the Maghreb region).

Regarding the types of immigrants, besides the 1994 manifesto that mentioned asylum seekers, refugees, and family reunification (PQ, 1994, types, 59:47,59:48,59:49,59:50), the PQ emphasised different categories of economic immigrants (skilled migrants, international students, etc.). In general, immigration is presented as a 'benefit' (PQ, 1994, volume, 59:4; 2003, other, 48:7) and, as to the three subcategories, adjustments to selection grids for issues of language and skills are framed as a way to ensure a better match between the province's needs and to reinforce the integration of immigrants (PQ, 2012, volume, 14:11; 2014, other, 7:16).

Regarding the jurisdiction axis, the PQ is strongly committed to an immigration system managed by Quebec, although this does evolve over time. The 1994 manifesto directly linked immigration to the issue of sovereignty: 'As a sovereign state, Quebec will acquire a new responsibility: to determine its immigration policy.' (PQ, 1994, jurisdiction, 59:3). This manifesto proposed an extremely liberal vision of immigration in relation to the goal of sovereignty: an independent Quebec was presented as an open space for immigrants of all origins and categories, and independence was a necessary condition for Quebec to be able to decide on its immigration policy. The associated commitments must be read in relation to the preparation for the 1995 referendum and the need for the party to fight accusations of being anti-immigrant and of espousing a form of ethnic nationalism. 
In subsequent elections, the PQ presented a more subdued position on the management of immigration within the federation. Pushing aside the issue of sovereignty, the party became committed to 'reclaiming' immigration powers (PQ, 2008, jurisdiction, 22:19) and then managing immigration with the 'means at its disposition.' (PQ, 2012, jurisdiction, 14:8; 2014, jurisdiction, 7:15). Thus, after 1994, the PQ's immigration commitments remained within the bounds of the 1991 Agreement. The 2018 manifesto partially broke with that pattern. On the one hand, the PQ argued that all of its proposals should be implemented without renegotiating the 1991 Agreement with Ottawa (PQ, 2018, jurisdiction, 1:35). On the other hand, hinting at the situation at the Canada-US border, the party re-emphasised the link between immigration and independence by stating that only a sovereign Quebec could manage its own borders and determine its own immigration criteria (PQ, 2018, jurisdiction, 1:15).

To conclude, the PQ's manifestos are decidedly pro-immigration, with a nationalist twist emphasising French-language prerequisites and Quebec's jurisdiction.

\section{Parti Libéral du Québec}

Between 1994 and 2012, the PLQ has remained staunchly pro-immigration. When it comes to volume, successive manifestos included commitments to raising or adjusting immigration levels as a way to benefit the province. These increases were presented as important not only to ensure that the province maintains a considerable population base within Canada (PLQ, 1998, volume, 55:4) but also to 'support Quebec's economic development' (PLQ, 2007, volume, 29:16). The few commitments associated with immigrant origins were very open (PLQ, 1994, origins, 58:13) and some criticised the balance between economic selection and language level in immigrant selection criteria. For example, in 2003, the PLQ argued that French-speaking immigration targets should not become exclusive quotas, which could lead to the rejection of immigrants fulfilling a shortage of labour and willing to learn French (PLQ, 2003, origins, 39:1). In 2007, the party also committed to recruit and selection immigrants originating from rural regions abroad, hoping they would settle outside of Montreal (PLQ, 2007, origins, 29:31). In relation to immigration types, the PLQ centred its commitment around economic categories, in particular those of workers, entrepreneurs, and international students (PLQ, 1998, types, 55:4; PLQ, 2003, types, 39:17; PLQ, 2007, types, 29:30; PLQ, 2012, types, 12:11,12:12). In 2018, the PLQ did not issue a full campaign manifesto but worked through a series of daily announcements. Generally speaking, its position seemed coherent with its previous positioning: the PLQ focused on the reform of the immigration policy that the government had just implemented (Paquet and Tomkinson 2018), while announcing an incremental increase in immigration levels without, however, stating clear targets (Schué and Donahue 2018).

The PLQ's manifestos were almost mute on the issue of how to manage immigration within the federation, with the exception of the 1994 and 1998 documents. In 1994, the party presented no commitment on the issue but did claim credit for the 1991 Agreement, which was signed by a Liberal minister. They argued that the agreement allowed for a 'better alignment of the immigration policies with our cultural and linguistic specificities' (PLQ, 1994, jurisdiction, 58:4). In the 1998 manifesto, the party also eschewed commitments but denounced the negative impact of the 1995 referendum and the potential of Quebec's separation from Canada on immigrant attraction (PLQ, 1998, jurisdiction, $55: 14,55: 15)$. 
The analysis of the PLQ's manifestos demonstrates that the party's official position on immigration has seldom moved. The central characteristics of PLQ's approach to immigration during elections appear to limit commitments as much as possible and to strongly underline the need to open immigration for economic reasons. The PLQ has thus remained staunchly pro-immigration and in line with a moderate position on the jurisdiction axis.

\section{Action Démocratique du Québec}

During the period studied, the ADQ directly spoke of immigration in only two of its manifestos: 2003 and 2007. Although these documents are limited, they point to a surprisingly liberal stance on immigration for a party that has often been described as anti-immigrant in comparative research.

The 2003 manifesto made several liberal commitments regarding immigration. Regarding volume, the ADQ argued for increasing immigration levels (ADQ, 2003, volume, 60:4,60:5,60:10), as 'Quebec receives only one in seven immigrants to Canada, while we represent almost a quarter of the population.' (ADQ, 2003, volume, 60:3). In the same year, the party also argued for more skilled and French-speaking workers (ADQ, 2003, types/origins, 60:16). When it comes to the centre-periphery axis, only the 2008 manifesto suggested a related commitment: the party proposed defending the areas of Quebec's jurisdiction and fighting to recognise exclusive power regarding several issues, including immigrant selection (ADQ, 2008, jurisdiction, 18:9). In so doing, the ADQ did not point to the 1991 Agreement or to specific immigration categories. While this commitment highlights the importance of the periphery, it does not allow us to position the party on the jurisdiction axis.

To conclude, the limited period of activity of the ADQ in Quebec's electoral politics makes it difficult to ascertain whether the party's positions have evolved over time. Electoral materials do, however, highlight two important elements. First, the CAQ is more than a mere continuation of the ADQ, as it will be explored in the next section. Second, our analysis does not position the ADQ as a restrictive party regarding immigration. Analyses labelling ADQ as 'anti-immigrant' have focused on the party's stances on reasonable accommodation and other diversity-related issues (Hepburn 2011). These positions indeed had to do with the presence of immigrants in the province but were wider in scope and, interestingly, were often not associated with official commitments related to lowering the number of immigrants admitted to the province.

\section{Coalition Avenir Québec}

During the period analysed, the CAQ has presented three manifestos to voters for provincial elections. In 2012, the CAQ released a long and substantive party manifesto of 114 pages. The principles laid out in this founding manifesto have been maintained throughout the following ones, even if the 2014 document is especially shy of immigration commitments.

In 2012, acknowledging that 'Quebec has welcomed an average of 44,000 immigrants a year in the last decade, including 54000 in 2010 alone' (CAQ, 2012, volume, 61:12), the CAQ committed to freezing immigration levels for 2 years: 
A Coalition Avenir Québec government will take two important steps following its election to ensure that immigration can make an optimal contribution to Québec's economic progress. The first step is to limit the number of immigrants to 45000 for a period of two years. The second is to use the downtime to establish resources and mechanisms that will maximise the employability of immigrants and ensure their harmonious integration into Québec's francophone majority. [CAQ,2012,volume,61:4,61:16]

While recognising the importance of immigration for demographic reasons (CAQ, 2012, volume, 61:8,61:20), the manifesto stated that the province's economy and integration system are incapable of absorbing as many immigrants as Quebec currently welcomes (CAQ, 2012, volume, 61:3). In 2018, the party again underlined this position by promising to decrease immigration levels by 20\% (CAQ, 2018, volume, 3:8). As concerns origin, the party suggested making sure that immigrants have a working level of French (CAQ, 2012, origins, 61:5). As for other political parties, these commitments would have indirect effects on regions and countries of origin. Regarding the immigration types, the CAQ strongly supports economic immigrants, focusing on the 'labour market' and the 'employability' of newcomers (CAQ, 2012, categories, $61: 2,61: 5,61: 11,61: 16)$. The CAQ is also distinct from other parties and past approaches on one point: its focus on the category of family reunification. In 2012 and later, the party linked this immigration stream, actually managed by Ottawa, with the necessity of Quebec being responsible for the selection of a larger part of the immigrants settling in the province (CAQ, 2012, categories, 61:7, 61:18, 61:19).

On the jurisdiction axis, the CAQ presented its position as an in-between, aiming at 'increasing Quebec's responsibilities' (CAQ, 2012, jurisdiction, 61:6). Indeed, between 2012 and 2018, the CAQ committed to revisiting the current institutional arrangements associated with the 1991 Agreement. In 2012, the party pledged to enter into negotiations with Ottawa to gain a 'better control of immigrant selection', while also allowing Quebec to link immigration and integration requirements as 'those who have not yet been integrated into the job market after two years could lose their selection certificate and never receive their permanent residency visa.' (CAQ, 2012, jurisdiction, 61:11,61:22). This measure was central and intensely discussed a few years later, during the 2018 electoral campaign, with CAQ's proposal to implement a mandatory test on language and Quebec values and to ask Ottawa to remove immigrants who did not meet the standard after 3 years (Castonguay 2018). In addition, the CAQ claimed to have a say regarding the category of family reunification because it is 'a considerable proportion of immigrants (20\% in 2010)' admitted into Quebec (CAQ, 2012, jurisdiction, 61:7). In 2014, the party criticised the current arrangement as generating overlaps and extra costs for taxpayers (CAQ, 2014, jurisdiction, 4:2).

The three manifestos available demonstrate that, relatively, the CAQ is the Quebec party that positions itself most towards the 'anti-immigration' side of the restrictiveliberal axis. When it comes to the jurisdiction axis, the party is situated further towards Quebec than the PLQ, and somewhat differently than the PQ as well. The CAQ's manifestos have brought forward two new items: the decrease of immigration levels and the renegotiation of the 1991 Agreement to have more jurisdiction, especially regarding family reunification. Interestingly, these positions were clearly stated in the party's 2012 manifesto but did not feature heavily in the CAQ electoral strategy at that 
point. However, they did attract a lot of media and political attention in 2018 and they are at the forefront of CAQ's governmental action in immigration matters.

\section{Québec Solidaire}

Between 2006 and 2018, Québec Solidaire made almost no immigration commitments. Most of its promises focused on issues related to immigrant integration from a social justice lens, with pledges to better recognise credentials and to offer more funding for education, employment services, and French-language training. However, the party's manifestos did not discuss immigration volume, origins, types, or jurisdiction. The only indirect exception concerns the 2008 manifesto: QS highlighted the need to ensure that all financial transfers received from Ottawa as part of the 1991 Agreement are used by the immigration ministry (QS, 2008, jurisdiction, 24:14). It is thus difficult to position QS on the restrictive-liberal and on the Canada-Quebec axes. Inferring a generally liberal and Quebec-favouring stance appears possible.

These results show that Quebec party positions on immigration have remained relatively stable between 1991 and 2018. On the immigration policy axis, the PLQ, the PQ, and even the ADQ have agreed on incremental increases of immigration levels (volume), with a common framing of immigration as a demographic and economic benefit. Entering the electoral arena in 2012, the CAQ officially broke with that consensus by rejecting immigration increases and adopting a more restrictive stance compared with other parties. Regarding origins, the results underline that the PQ and the CAQ have both focused on language with their commitment to increase Frenchspeaking immigrants' share. Regarding the types of immigrants favoured, all the political parties have expressed a positive assessment of economic immigrants. The CAQ is the only one to openly discuss family reunification and its consequences for Quebec, especially through the jurisdiction axis. With respect to the latter, Quebec party positions on immigration have aligned with their general orientation towards federalism. The PQ has been the most oriented towards Quebec - with some variation along the years (from a very sovereigntist position on immigration to more subdued proposals). The PLQ, to some extent, has defended the status quo, both by warning of the negative effects of sovereignty for immigration and by defending the 1991 Agreement. The CAQ has tried to distinguish its position by calling into question the modes of governance stemming from the 1991 Agreement. Due to its willingness to reopen the institutional arrangements, the CAQ also broke with the legacy of the PQ and the PLQ.

\section{Conclusion}

Representing the Quebec immigration partisan space as structured by a liberalrestrictive continuum and a Canada-Quebec axis, this article has documented how provincial parties have positioned themselves on immigration between 1991 and 2018. While Quebec parties have been relatively silent on immigration policy, their positions have remained stable over time. Cross-party variations on the topic mostly concern the level of government that should be in charge of immigration, illustrating the continued structuration of the centre-periphery cleavage in the province's party system. Up until 2012, Quebec's mainstream parties remained relatively close in their liberal views 
towards immigration. This came to a halt as the CAQ has actively focused on the less considered issue of immigration in Quebec from 2012 on. $^{5}$ This represents a major break from dominant party stances within the particular configuration of Quebec's partisan space, bringing more restrictive stances into the electoral sphere. This political reality cannot be understood without paying serious attention to context.

However, when compared with the immigration positions of RRPs and, increasingly, of mainstream political parties in other countries, the CAQ's immigration proposals could hardly be classified as anti-immigration or seriously restrictive. While the party has proposed a decrease in immigration intakes in 2018, it has done without completely turning its back on the positive value of immigration. Indeed, despite this electoral commitment, the CAQ identifies immigration as having positive consequences for the economy and the province labour market. This linkage helps explain an important post2018 policy outcome: immigration-level plans. Following the 2018 election, the government acted on its promise and announced a decrease in annual intakes for 2019. Yet, the CAQ's government also planned implementing incremental immigration increase for 2020-2022 (MIDI 2019). ${ }^{6}$ This decision hints at the strategic use of immigration as an issue during the 2018 election.

More generally, the CAQ's position towards immigrants is ambiguous. The party has adopted a contested bill on secularism (Bill 21) that bans religious symbols in most public sectors jobs, which will result in direct and indirect discrimination of some immigrants and religious minorities. At the same time, since 2018, they have made increased the funding and the availability of immigrant integration services, making them even available to temporary immigrants in Quebec. The coexistence of these measures and the gap between electoral discourses and policy outcomes demonstrate the need to better understand the ideological foundations of the CAQ when it comes to immigration.

Regarding Quebec, the politicisation could be the sign of new patterns. First, it is worth noting that immigration has not always been welcomed in the French-speaking province (Barker 2015). Indeed, prior to the 1960s, newcomers were primarily seen as a 'potential threat to traditional French culture and institutions' (Carens 1995, 21), and as a 'Trojan horse' serving the economic and demographic interests of the anglophones (Daniel 2006, 44). In the long-term story, this new positioning could figure a return to a more defensive position towards immigration. Second, on the federal scale, this pattern could either prefigure a stronger opposition between Quebec and the ROC ('rest of Canada') or could demonstrate that the federation and its provinces are not immune to controversy over immigration issues and the emergence of parties promoting more restrictive policies.

More generally, the case of Quebec confirms that mainstream parties can be the drivers behind the politicisation of immigration, with major implications for immigration scholars interested in immigration, parties, and elections. First, this case study acts as a reminder of the importance of adapting tools for the study of this phenomenon to less traditional configurations, including subnational units (regions, states, provinces, and cities) as well as cases with very low immigration intakes, or with high degree of effective government control on immigration flows. For example, the multidimensional

\footnotetext{
${ }_{5}^{5}$ In 2015, Simon Jolin-Barrette (the CAQ's spokesperson for immigration and, since 2018, the Quebec Minister in charge of immigration) released a 17-page document entitled 'A New Pact to Modernize Quebec's Immigration Policy'.

${ }^{6}$ This decision was made before the COVID-19 crisis.
} 
grid could lead to better study of the party stances on immigration in regions with nationalist mobilisations such as Catalonia, Flanders, and Scotland, where immigration claims should be informed both by a restrictive-liberal continuum and by the relationship with the central state (with divergence potentially coming from parties promoting more autonomy for the subnational unit). In these contexts, the politicisation of immigration might well exist but might be driven by other partisan motivations, revealing particular interests, strategies, and immigration sub-issues.

Second, the fact that mainstream parties cluster on the 'liberal' side of our immigration policy axis demonstrates the need to further develop conceptualisations and measurements of 'pro-immigration' positions. Indeed, the positions expressed by Quebec parties are generally open to immigration; yet they do remain qualitatively different from one another, leading to important political and administrative consequences. One starting point for further study of this issue is to disaggregate the analysis of immigration claims into different components, for example using Czaika and De Haas' (2013) three-pronged conceptualisation or Adam and Deschouwer's (2016) categories of immigration policy position. Additionally, an improved account of party dynamics and strategies when immigration is generally positively assessed or does not seem to be subject of polarisation is needed. For example, the category of 'skilled immigrants,' which is generally positively assessed and increasingly promoted by political parties, refers to a multifaceted category (Boucher 2020).

Third, since a central finding is that Quebec party manifestos remained somewhat mute on issues of immigration, this research also shows the importance of studying 'silence'. There are theoretical reasons to predict that parties might resist including clear immigration commitments in their electoral materials. As proposed by Freeman (1995), parties might not perceive voters as their main clients when it comes to immigration and instead focus their attention on more vote-rewarding issues. Work on parties and immigration also points to two other strategic drivers of 'active avoidance' regarding immigration. On the one hand, silence can result from internal tension over immigration within a political organisation (Ruedin and Morales 2017, 2). On the other hand, silence can be a consequence of the lack of electoral competitive advantage on the issue (Bélanger and Meguid 2008). Moreover, the changing nature of electoral campaigns and of political communication implies that manifestos themselves are changing as a medium. In the case of Quebec, as demonstrated by the list of documents analysed (see Appendix B), party manifestos have tended to become shorter over time and were even non-existent for some parties for the 2018 election. Whether party silence on immigration is either strategic or more pragmatic, these insights, while raising questions beyond the scope of this article, do point to the importance of considering other data sources and indicators when it comes to immigration politicisation.

\section{References}

Abou-Chadi, T. (2016a). Niche party success and mainstream party policy shifts - how green and radical right parties differ in their impact. British Journal of Political Science, 46(2), 417-436. https://doi.org/10.1017 /S0007123414000155.

Abou-Chadi, T. (2016b). Political and institutional determinants of immigration policies. Journal of Ethnic and Migration Studies, 42(13), 2087-2110. https://doi.org/10.1080/1369183X.2016.1166938. 
Adam, I., \& Deschouwer, K. (2016). Nationalist parties and immigration in Flanders: from Volksunie to Spirit and N-VA. Journal of Ethnic and Migration Studies, 42(8), 1290-1303. https://doi.org/10.1080/1369183 X.2015.1082285.

Alonso, S., \& da Fonseca, S. C. (2012). Immigration, left and right. Party Politics, 18(6), 865-884. https://doi. org/10.1177/1354068810393265.

Bale, T. (2008). Turning round the telescope. centre-right parties and immigration and integration policy in Europe1. Journal of European Public Policy, 15(3), 315-330. https://doi.org/10.1080 /13501760701847341.

Barker, F. (2015). Nationalism, identity and the governance of diversity. London: Palgrave Macmillan UK. https://doi.org/10.1057/9781137339317.

Béland, D., \& Lecours, A. (2005). The politics of territorial solidarity: nationalism and social policy reform in Canada, the United Kingdom, and Belgium. Comparative Political Studies, 38(6), 676-703. https://doi. org/10.1177/0010414005275600.

Bélanger, É. (2014). 'Party behaviour in Quebec: ownership, contagion, and multi-dimensionality of the national question'. In , 34. Edinburgh.

Bélanger, É., \& Meguid, B. M. (2008). Issue salience, issue ownership, and issue-based vote choice. Electoral Studies, 27(3), 477-491. https://doi.org/10.1016/j.electstud.2008.01.001.

Bélanger, É., Nadeau, R., Henderson, A., \& Hepburn, E. (2018). The National Question and Electoral Politics in Quebec and Scotland. Montreal: McGill-Queen's University Press.

Bilodeau, A., Turgeon, L., White, S., \& Henderson, A. (2018). Strange bedfellows? Attitudes toward minority and majority religious symbols in the public sphere. Politics and Religion, 11(2), 309-333. https://doi. org/10.1017/S1755048317000748.

Birkland, T. A. (1998). Focusing events, mobilization, and agenda setting. Journal of Public Policy, 18(1), 53-74.

Bloemraad, I. (2012). Understanding 'Canadian Exceptionalism'in immigration and pluralism policy. July: Migration Policy Institute.

Boily, F. (2008). Mario Dumont et l'Action démocratique du Québec: entre populisme et démocratie. Québec: Presses de l'Université Laval.

Boily, F. (2018). La Coalition Avenir Québec: une idéologie à la recherche du pouvoir. Québec: Presses de l’Université Laval http://www.deslibris.ca/ID/456057.

Boucher, A. K. (2020). How 'skill' definition affects the diversity of skilled immigration policies. Journal of Ethnic and Migration Studies, 46(12), 2533-2550. https://doi.org/10.1080/1369183X.2018.1561063

Brug, W. v. d., D’Amato, G., Berkhout, J., \& Ruedin, D. (2015). The politicisation of migration. London: Routledge http://site.ebrary.com/id/11037955.

Carens, J. H. (1995). Immigration, political community, and the transformation of identity: Quebec's immigration politics in critical perspective. In Is Quebec nationalism just? : Perspectives from Anglophone Canada, by Joseph H. Carens (pp. 20-81). Montreal: McGill-Queen's University Press.

Carvalho, J., \& Ruedin, D.. (2018). 'The positions mainstream left parties adopt on immigration: A crosscutting cleavage?’ Party Politics, June, 135406881878053. https://doi.org/10.1177/1354068818780533.

Castonguay, A.. (2018). 'Immigration : François Legault Met Cartes Sur Table'. L'actualité, mai 2018. https://actualite.com/politique/elections-2018/2018/05/14/immigration-francois-legault-met-cartes-surtable/.

Chouinard, T. (2018). 'C'est La “Question de l'urne”, Dit Couillard'. La Presse, 11 September 2018.

Czaika, M., \& De Haas, H. (2013). The effectiveness of immigration policies. Population and Development Review, 39(3), 487-508. https://doi.org/10.1111/j.1728-4457.2013.00613.x.

Dancygier, R., \& Margalit, Y. (2019). The evolution of the immigration debate: evidence from a new dataset of party positions over the last half-century. Comparative Political Studies, July, 001041401985893. https://doi.org/10.1177/0010414019858936.

Daniel, D. (2006). 'La politique d'immigration du Québec'. In J. Crête (ed.), Politiques Publiques : Le Québec Comparé (pp. 43-69). Québec: Presses de l’Université Laval.

Dennison, J., \& Geddes, A. (2018). A rising tide? The salience of immigration and the rise of anti-immigration political parties in Western Europe. The Political Quarterly. https://doi.org/10.1111/1467-923X.12620.

Erk. (2014). FPTP Ain't all Thath bad: nationalist parties, immigrants, and electoral systems in Québec and Flanders. In E. Hepburn \& R. Zapata-Barrero (Eds.), The politics of immigration in multi-level states (pp. 223-2406). London: Palgrave Macmillan UK.

Filindra, A., \& Goodman, S. W. (2019). Studying public policy through immigration policy: advances in theory and measurement. Policy Studies Journal, July. https://doi.org/10.1111/psj.12358. 
Fletcher, R. (2018). 'Immigration the "ballot box" question in Quebec election, Couillard Says'. Global News. 10 September 2018. https://globalnews.ca/news/4438851/couillard-says-immigration-the-ballot-boxquestion-in-quebec-election/.

Freeman, G. P. (1995). Modes of immigration politics in liberal democratic states. International Migration Review, 29(4), 881-902. https://doi.org/10.1177/019791839502900401.

Gagnon, A.-G., \& Iacovino, R. (2007). Federalism, Citizenship and Quebec. Toronto: University of Toronto Press.

Garon, F. (2015). Policy-making for immigration and integration in Québec: degenerative politics or business as usual? Policy Studies, 36(5), 487-506. https://doi.org/10.1080/01442872.2015.1089984.

Gest, J., \& Boucher, A. (2018). Crossroads: Comparative Immigration Regimes in a World of Demographic Change. Cambridge, UK; New York, NY: Cambridge University Press.

Grande, E., Schwarzbözl, T., \& Fatke, M. (2019). Politicizing immigration in Western Europe. Journal of European Public Policy, 26(10), 1444-1463. https://doi.org/10.1080/13501763.2018.1531909.

Green-Pedersen, C., \& Otjes, S. (2017). A hot topic? immigration on the agenda in Western Europe. Party Politics, August. https://doi.org/10.1177/1354068817728211.

Hainmueller, J., \& Hopkins, D. J. (2014). Public attitudes toward immigration. Annual Review of Political Science, 17(1), 225-249. https://doi.org/10.1146/annurev-polisci-102512-194818.

Hammar, T. (1985). European immigration policy: a comparative study. Cambridge: Cambridge University Press. https://doi.org/10.1017/CBO9780511898143.

Hepburn, E. (2011). "Citizens of the region": party conceptions of regional citizenship and immigrant integration. European Journal of Political Research, 50(4), 504-529. https://doi.org/10.1111/j.14756765.2010.01940.x.

Hobolt, S. B., \& de Vries, C. E. (2015). Issue entrepreneurship and multiparty competition. Comparative Political Studies, 48(9), 1159-1185. https://doi.org/10.1177/0010414015575030.

Houle, F. (2014). Implementing Québec intercultural policy through the selection of immigrants. In S. Baglay \& D. Nakache (Eds.), Immigration Regulation in Federal States (pp. 117-138). International Perspectives on Migration. Dordrecht: Springer Netherlands.

Inglehart, R., \& Norris, P. (2017). Trump and the populist authoritarian parties: the silent revolution in reverse. Perspectives on Politics, 15(2), 443-454. https://doi.org/10.1017/S1537592717000111.

Kelle, U., Prein, G., \& Bird, K. (1995). Computer-aided qualitative data analysis: theory, methods and practice. London; Thousand Oaks, Calif: Sage Publications.

Lawlor, A. (2015). Framing immigration in the Canadian and British news media. Canadian Journal of Political Science, 48(2), 329-355. https://doi.org/10.1017/S0008423915000499.

Laxer, E., Carson, R. D., \& Korteweg, A. C. (2014). Articulating minority nationhood: cultural and political dimensions in Québec's reasonable accommodation debate. Nations and Nationalism, 20(1), 133-153. https://doi.org/10.1111/nana.12046.

Meyer, S., \& Rosenberger, S. (2015). Just a shadow? The role of radical right parties in the politicization of immigration, 1995-2009. Politics and Governance, 3(2), 1. https://doi.org/10.17645/pag.v3i2.64.

MIDI, Ministère de l'Immigration, de la Diversité et de l'Inclusion. (2019). 'La Planification de l'immigration Au Québec Pour La Période 2020-2022. Cahier de Consultation.' Cahier de consultation F-1633-FR. Montréal: Direction de la planification de l'immigration.

Montigny, É., \& Gélineau, F. (2019). Boussole Électorale et Configuration d'un Système Partisan : Le Cas Du Québec. In P. Poirier \& N. Fahrat (Eds.), Démocratie(s), Parlementarismes(s) et Légitimité(s) / Democracy(Ies), Parliamentarism(s) and Legitimacy(Ies) (pp. 163-184). Bruylant: Bruxelles.

Montpetit, J. (2016). 'Inside Quebec's far right: a secretive online group steps into the real world'. CBC News, 4 December 2016. https://www.cbc.ca/news/canada/montreal/quebec-far-right-la-meute-1.3876225.

Morales, L., Pilet, J.-B., \& Ruedin, D. (2015). The gap between public preferences and policies on immigration: a comparative examination of the effect of politicisation on policy congruence. Journal of Ethnic and Migration Studies, 41(9), 1495-1516. https://doi.org/10.1080/1369183X.2015.1021598.

Paquet, M. (2017). Les Politiques Migratoires. In A.-G. Gagnon \& D. Sanschagrin (Eds.), La Politique Québécoise et Canadienne. Acteurs, Institutions, Sociétés. 2e Édition. Montreal: Presses de l’Université du Québec.

Paquet, M. (2019). Province-building and the federalization of immigration in Canada. Toronto: University of Toronto Press.

Paquet, M. (2020). La « sélection efficace » des immigrants : paradigme de la mobilité et légitimité de l'État québécois. Diversité urbaine, 20(1). https://doi.org/10.7202/1068222ar.

Paquet, M., \& Tomkinson, S. (2018). Petites Promesses, Réalisations Structurantes : Les Politiques Migratoires et Le Gouvernement Couillard. In F. Pétry \& L. Birch (Eds.), Bilan des Réalisations Du 
Gouvernement Couillard. 150 Promesses et 1 Mandat (pp. 277-294). Québec: Presses de 1'Université Laval.

Rivard, A. (2017). Plus ça change...: The Effects of Nationalism and Electoral Competition on Immigration and Integration Policy Proposals in Quebec, 1976-2014. M. A. Thesis. Montréal: Concordia University. https://spectrum.library.concordia.ca/982374/

Ruedin, D. (2019). South African parties hardly politicise immigration in their electoral manifestos. Politikon, 46(2), 206-218. https://doi.org/10.1080/02589346.2019.1608713.

Ruedin, D., \& Morales, L. (2017). Estimating party positions on immigration: assessing the reliability and validity of different methods. Party Politics, June. https://doi.org/10.1177/1354068817713122.

Schain, M. A. (2002). The impact of the French National Front on the French Political System. In M. Schain, A. Zolberg, \& P. Hossay (Eds.), Shadows over Europe (pp. 223-243). New York: Palgrave Macmillan US. https://doi.org/10.1057/9780230109186_10.

Schué, R., \& Donahue Y. (2018). 'L’immigration Sera Le Sujet Décisif de l'élection, Juge Couillard'. RadioCanada, 10 September 2018. https://ici.radio-canada.ca/nouvelle/1122852/plq-main-oeuvre-immigrationfrancisation-elections-quebec.

Tanguay, A. B. (2013). Epitaph for a conservative insurgency in Quebec: the rise and fall - and rise and fall of the Action démocratique du Québec, 1994-2008. In J. Farney and D. Rayside (Eds). Conservatism in Canada (pp. 317-338). Toronto: University of Toronto Press.

Tessier, C., \& Montigny, É. (2016). Untangling myths and facts: who supported the Québec charter of values? French Politics, 14(2), 272-285. https://doi.org/10.1057/fp.2016.1.

Turgeon, L., \& Bilodeau, A. (2014). Minority nations and attitudes towards immigration: the case of Quebec. Nations \& Nationalism, 20(2), 317-336. https://doi.org/10.1111/nana.12068.

van Spanje, J. (2010). Contagious parties: anti-immigration parties and their impact on other parties' immigration stances in contemporary Western Europe. Party Politics, 16(5), 563-586. https://doi. org/10.1177/1354068809346002.

Xhardez, C. (2020). Immigration federalism, multinational states and subnational communities: comparing Flanders and Quebec. In A.-G. Gagnon \& A. Tremblay (Eds.), Federalism and National Diversity in the 21 st Century (pp. 209-239). Cham: Springer international publishing. https://doi.org/10.1007/978-3-03038419-7 9.

Publisher's Note Springer Nature remains neutral with regard to jurisdictional claims in published maps and institutional affiliations. 